\title{
The Interaction of the Principal Purpose Test (and the Guiding Principle) with Treaty and Domestic Anti-Avoidance Rules
}

\author{
Vikram Chand*
}

\begin{abstract}
In the previous contribution, which carried out a detailed analysis of the principal purpose test (PPT), the author had indicated that interesting issues arise with respect to the interaction of the PPT (and the guiding principle) with other treaty based or domestic based anti-avoidance rules. In this contribution, the author, firstly, discusses the interaction of the test with the inherent anti-abuse rule. Secondly, the author discusses the relationship of this test with existing treaty general anti-avoidance rules (GAARs) and specific anti-avoidance rules (SAARs) such as the limitation of benefits clause, the beneficial ownership clause, holding/time period provisions introduced in the articles dealing with dividends/capital gains as well as the anti-abuse rule with respect to permanent establishments in a third State. Lastly, the author analyses the interaction of the PPT with domestic anti-avoidance rules such as judicial doctrines, statutory GAARs and SAARs. It is pertinent to note that this contribution should be read in conjunction with the author's previous contribution published in the January edition of the journal.
\end{abstract}

\section{INTRODUCTION}

1. In the previous contribution, which carried out a detailed analysis of the principal purpose test (PPT), the author had indicated that interesting issues arise with respect to the interaction of the PPT (and the guiding principle) with other treaty based or domestic based anti-avoidance rules. In this contribution, the author, firstly, discusses the interaction of the test with the inherent anti-abuse rule (see section 2). Secondly, the author discusses the relationship of this test with existing treaty general anti-avoidance rules (GAARs) and specific anti-avoidance rules (SAARs) such as the limitation of benefits (LOBs) clause, the beneficial ownership clause, holding/time period provisions introduced in the articles dealing with dividends/capital gains as well as the anti-abuse rule with respect to permanent establishments (PEs) in a third State (see section 3). Lastly, the author analyses the interaction of the PPT with domestic anti-avoidance rules such as judicial doctrines, statutory GAARs and SAARs (see section 4). Finally, the author concludes (see section 5). It is pertinent to note that this contribution should be read in conjunction with the author's previous contribution published in the preceding edition of the journal.

\section{THE INHERENT ANTI-ABUSE RULE}

2. Article 38(1)(c) of the UN Statute of the International Court of Justice provides that the Court shall apply 'the general principles of law recognized by civilized nations' to the submitted disputes. It is argued that such 'general principles of law' are a source of international law. Consequently, such principles should be taken into consideration to interpret tax treaties. Specifically, it is argued that the 'abuse of rights' doctrine can be considered as a 'general principle of law' for the purposes of Article $38(1)(c)$ and thus can be used to interpret tax treaties. This is because several civil law countries and International Courts have developed and applied the 'abuse of rights' doctrine in non-tax law and tax law cases. Alternatively, it is argued that an antiabuse doctrine in tax matters exists at the level of international law independently of whether the abuse of rights doctrine exists at the level of international law. This is primarily because the domestic laws of several States contain domestic anti-avoidance rules. Thus, as there is a unanimous acceptance of anti-abuse rules, such rules meet the requirements of Article 38(1)(c). Furthermore, on an independent footing, it has also been argued that the

\section{Notes}

Executive Director - International Tax Education (Masters of Advanced Studies in International Taxation and Executive Program in Transfer Pricing), Tax Policy Center of the University of Lausanne, Switzerland. Email: vikram.chand@unil.ch. The author would like to thank Mr Quentin Oyon and Mr Benjamin Malek(researchers at the Tax Policy Center) for their assistance with respect to this article. 
principle of 'good faith' enshrined in Article 26 or Article 31(1) of the Vienna Convention of the Law on Treaties (VCLT) includes the prohibition of abuse. Accordingly, by referring to Article 38(1) (c) and/or the principle of 'good faith', it is contended that an 'inberent anti-abuse rule' exists in tax treaties and that rule can counter treaty abuse (such as treaty shopping or rule shopping). However, commentators $^{1}$ and national courts ${ }^{2}$ seem to be divided in their opinion on the existence and application of such an anti-abuse rule to tax treaties. In the author's opinion, such a rule does not exist given its undefined nature and therefore cannot be used to counter treaty abuse. ${ }^{3}$ Moreover, even if it is demonstrated that such a rule exists (as it is applied in certain States) and a tax treaty contains the PPT, in the author's opinion, the treaty PPT will prevail over the inherent anti-abuse rule. This is because the treaty PPT is a written anti-avoidance rule and can be considered to be a 'lex specialis' in comparison to the unwritten anti-abuse rule. ${ }^{4}$

\section{Treaty ANTI-AVOIDANCE RULES}

\section{I Treaty GAARs}

3. Article $7(2)^{5}$ of the Multilateral Instrument (MLI), the compatibility clause, provides that the PPT shall be included 'in place of or in the absence of' similar provisions of all Covered Tax Agreements. ${ }^{6}$ This means that the PPT will replace existing treaty GAARs that apply to deny all treaty benefits ${ }^{7}$ or benefits sought under selected provisions. ${ }^{8}$ Moreover, this also means that the PPT will be added to tax treaties that do not contain any treaty GAARs. ${ }^{9}$ If the relevant tax treaty would incorporate the PPT, then, in the opinion of the author, there is no need to resort to the guiding principle that is derived from the commentary.

\subsection{Treaty SAARs}

\subsection{Introductory Comments}

4. If one applies the interpretation doctrine of lex specialis derogat legi generali then the treaty SAARs should prevail over the guiding principle (which is derived from the commentary) when such anti-abuse rules apply to similar fact patterns. A similar outcome should have applied in the context of the PPT. However, the PPT applies 'notwithstanding the other provisions of this Convention'. By using a non-obstante clause the PPT becomes a self-standing (overriding) provision and applies even if the transaction undertaken by the taxpayer passes the tests of the treaty SAARs such as the LOB clause ${ }^{10}$ or the beneficial ownership clause (found in Articles 10, 11 and 12 OECD Model) ${ }^{11}$ or the other SAAR's introduced through the MLI viz., Article 8, Article 9 or Article 10 of the MLI. This is surely an unreasonable outcome. ${ }^{12}$ In line with the position expressed with respect to the guiding principle, the author's opinion is that the transaction/arrangement can be analysed under the PPT only when the treaty SAAR does not cover the factual situation at stake. ${ }^{13}$ This is explained below.

\section{Notes}

Concurring with the existence: Ward, Abuse, at 18-26; Vogel, Commentary, at 125; Engelen, Good Faith, at 36. Dissenting with the existence: Van Weeghel, Thesis, at 98-102; De Broe, Thesis, at 302-316; Chand, Thesis, s. 21.3.1.1.

Accepted: Swiss Supreme Court in A Holding ApS v. Federal Tax Administration, 8 ITLR 536, 536-562 (28 Nov. 2005) and District Court of Tel Aviv-Yafo: Yanko-Weiss Holdings Ltd v. Holon Assessing Office, 10 ITLR 524, 524-550 (30 Dec. 2007). Rejected: Vodafone International Holdings B.V. vs Union of India, Civil Appeal No.733 of 20 Jan. 2012 and MIL (Investments) SA v. Canada, 9 ITLR 25 (18 Aug. 2006).

See Chand, Thesis, s. 21.3.1.1

De Broe, EU Law, at 226.

2016 OECD, Multilateral Convention, Art. 7(2)

See 2016 OECD, Explanatory Statement to the Multilateral Convention, paras 93-96.

Several tax treaties concluded by India contain a treaty GAAR that could deny all benefits under a tax treaty. See India, MLI Position, at 26-27. These provisions will be replaced by the PPT. For instance, the limitation of benefit provision contained in Art. 28(C), India-UK Tax Treaty (1993 as updated with the 2013 protocol) or Art. 29(2-3), India-Luxembourg Tax Treaty (2008) will be replaced by the PPT. Although these provisions are called limitation of benefit provisions, in principle, they are treaty GAARs.

8 Several tax treaties concluded by the UK include 'main purpose tests', especially, with respect to articles that deal with dividends, interest and royalties. See UK, MLI Position, at 37-40. These provisions will be replaced by the PPT. For instance, the anti-conduit provision contained in Art. 3(1)(n), UK-US Tax Treaty (2001) will be replaced with the PPT if the US signs the MLI.

9 Several tax treaties concluded by the Netherlands do not have Treaty GAARs. See Dutch, MLI Position, at 26-27. The PPT will be added to Dutch tax treaties. For instance, the PPT will be added to the India-Netherlands Tax Treaty (1988 as updated with the 2012 protocol).

102017 OECD Comm (Draft), Art. 29, para. 8.

11 The clause can be considered to be an anti-avoidance clause. See 2017 OECD Comm (Draft), Art. 1, para. 63; De Broe \& Luts, BEPS, at 133.

12 Lang, PPT rule, at 655; De Broe, Luts, BEPS, at 133.

13 The author is currently undertaking further research with respect to the scope of non-obstante clauses. 


\subsubsection{PPT and $L O B$}

5. Assume that the R-S tax treaty has a PPT and the simplified $\mathrm{LOB}^{14}$ in all the examples discussed in this section as a result of the MLI. Moreover, State $\mathrm{R}$ exempts dividend income from taxation under its domestic law through a participation exemption regime whereas interest income is taxed at the normal corporate tax rate (for instance, $12.5 \%)$. State $\mathrm{S}$ imposes a $25 \%$ domestic withholding tax on passive income (dividends and interest).

6. Consider the following situation. A pure holding company - RCO, resident of State R, which is wholly owned by TCO, a resident of a third State (State T - a State that does not have a tax treaty with State $S$ ), will not satisfy the LOB clause. Specifically, the holding company will not be a 'qualified person' for the purpose of Article 7(9) of the MLI, ${ }^{15}$ it may not satisfy the active conduct test as a result of Article 7(10)(i) of the $\mathrm{MLI}^{16}$ and it will not satisfy the derivative benefit test contained in Article 7(11) of the MLI ${ }^{17}$ (as it is owned by residents of a third State i.e. by non-equivalent beneficiaries). Therefore, this entity will be denied treaty benefits with respect to dividend related income that stems from its participations in companies that are residents of State $S$. In this situation, the LOB clause will take precedence to deny treaty access and the PPT (or guiding principle) will not apply. ${ }^{18}$

7. Changing the facts, consider another situation where a tax treaty exists between State $\mathrm{T}$ and State $\mathrm{S}$ and that treaty provides for benefits similar to the $\mathrm{R}-$ $\mathrm{S}$ tax treaty with respect to dividend related income (both treaties exempt dividend income from source taxation). In this case, the pure holding company (RCO), which does not satisfy Article 7(9) or Article 7(10)(i), may satisfy Article 7(11) $)^{19}$ of the simplified LOB (that deals with derivative benefits) as it is owned by an equivalent beneficiary ${ }^{20}$ viz., TCO (beneficiary in State $\mathrm{T}$ that would have been entitled to a similar treaty benefit had it invested directly). In this situation, this entity will be granted treaty benefits under Article 7(11) with respect to dividend related income that flows from its participations in companies that are residents of State S. Can the PPT be applied by State $S$ to the holding company to deny treaty benefits? In the author's opinion, the PPT should not apply to a fact pattern that falls under the scope of the LOB and in such situations the interpretation doctrine of lex specialis derogat legi generali should continue to apply ${ }^{21}$ (the guiding principle should definitely not apply). Even if the PPT is applied and the subjective element gets satisfied (as the sole purpose for the holding company is to obtain treaty benefits), the author's opinion is that the taxpayer may be able to establish that it has acted in accordance with the 'object and purpose of the relevant provisions' read in light of the treaties preamble (objective element). Specifically, the taxpayer may argue that it acts in accordance with the relevant provisions of the derivative benefits clause. Moreover, it may be able to establish that this situation does not represent a treaty shopping case that entails passing the income for the benefit of third State residents. In other words, both treaties (R-S and $\mathrm{T}-\mathrm{S}$ ) offer equal protection and investing with or without the holding company would not make a difference with respect to taxes levied in State S. The argument that the taxpayer does not pay any taxes under domestic tax law of State $\mathrm{R}$ (pursuant to the domestic participation exemption) should not be relevant to the application of the PPT in this situation as a benefit under the domestic law would fall outside the scope of the PPT.

8. Moving on, consider the facts contained in Example $\mathrm{F}^{22}$ to the commentary on anti-conduits. In that case, $\mathrm{RCO}$, an operational financing entity, is owned by a resident of State T. State $\mathrm{T}$ does not have a tax treaty with State S. In this situation, RCO will not be a 'qualified person' for the purpose of Article 7(9), it may not satisfy the active conduct test as a result of Article 7 (10)(iii) $)^{23}$ as it provides intra group financing and it will

\section{Notes}

14 For instance, the PPT and Simplified LOB will be added to the India-Denmark Tax Treaty (1989 as amended subsequently).

152016 OECD, Multilateral Convention, Art. 7(9).

162016 OECD, Multilateral Convention, Art. 7(10); 2017 OECD Comm (Draft), Art. 29, para. 73.

172016 OECD, Multilateral Convention, Art. 7(11).

182015 OECD, Final Report on Treaty Abuse, para. 26 (Commentary in para. 3); 2017 OECD Comm (Draft), Art. 29, para. 171.

192017 OECD Comm (Draft), Art. 29, para. 82 and para. 87.

202017 OECD Comm (Draft), Art. 29, paras 128-130.

21 Danon \& Salome, MLI, s. 3.7.1.

222015 OECD, Final Report on Treaty Abuse, para. 26 (Commentary in para. 19, Example F); 2017 OECD Comm (Draft), Art. 29, para. 187, Example F.

232017 OECD Comm (Draft), Art. 29, para. 73. 
not satisfy the derivative benefit test contained in Article 7(11) of the MLI (as it is owned by non-equivalent beneficiaries). Assume that RCO applies for discretionary relief under Article 7(12) of the MLI and the competent authorities agree to extend the relief based on non-tax reasons. ${ }^{24}$ Can the PPT be applied to deny treaty benefits? In the author's opinion, once again, the interpretation doctrine of lex specialis derogat legi generali should continue to apply ${ }^{25}$ with the result that the PPT is not applicable (the guiding principle should definitely not apply). At the outset, it will be extremely absurd if the State S local tax authorities apply the PPT to deny treaty benefits that have been granted by the competent authorities. Even if applied, as demonstrated in the previous contribution, the subjective element of the PPT will not be satisfied with respect to this fact pattern (see section 4.3.2.5 of the previous contribution). Furthermore, the author's opinion is that the taxpayer may be able to establish that it has acted in accordance with the 'object and purpose of the relevant provisions' read in light of the treaties preamble (objective element). Specifically, the taxpayer may argue that it acts in accordance with the relevant provisions of the discretionary relief clause (which grants benefits only when non-tax reasons exist).

9. On the other hand, the PPT (or guiding principle) could be applied to fact patterns that are not caught by the LOB. For example, a listed financial institution, a State $\mathrm{R}$ resident, will always satisfy the $\mathrm{LOB}$ clause i.e. it is a qualified person within the meaning of Article 7 (9)(c) of the MLI. Assume that the financial institution enters into a conduit financing arrangement with the sole purpose of avoiding taxes in the State of source for the benefit of third State residents (State T - a State that does not have a treaty with State S). In these circumstances, it cannot be argued that the PPT (or guiding principle) cannot be applied to the conduit financing arrangement (the arrangement represents an additional factual pattern) with the effect that the treaty benefit will be denied. ${ }^{26}$
10. This being said, the outcome could be different if we assume that State $\mathrm{T}$ has a tax treaty with State $\mathrm{S}$ that provides for equivalent benefits with respect to interest related income (both treaties exempt interest income from source taxation). If the PPT is applied and the subjective element gets satisfied (as the sole purpose is to obtain treaty benefits), the author's opinion is that the taxpayer may be able to establish that it has acted in accordance with the 'object and purpose of the relevant provisions' read in light of the treaties preamble (objective element). Specifically, the taxpayer may be able to establish that this situation does not represent a treaty shopping case that entails passing the income for the benefit of third State residents. ${ }^{27}$ In other words, both treaties offer equal protection and investing with or without the financing arrangement would not make a difference with respect to taxes levied in State $S^{28}$ The argument that the taxpayer pays low corporate income taxes under the domestic tax law of State $\mathrm{R}$ (for instance, on the interest spread) should not be relevant to the application of the PPT in this situation.

\subsubsection{PPT and Beneficial Ownership}

11. The commentary to the PPT indicates that the PPT could be applied to a 'resident of the other State (who is the beneficial owner) under Article 10, 11 or 12,29

12. It is clear that agents and nominees (for instance, individuals or companies) cannot be regarded as 'beneficial owners' as they receive income on behalf of others. ${ }^{30}$ In these situations, the PPT should not be applied as the 'beneficial owner' clause will tackle treaty abuse issues with respect to the income collected by agent and nominees. For instance, see the discussion in the previous contribution (see section 4.3.2.11 of the contribution) with respect to Example $\mathrm{I}^{31}$ that deals with the collection of royalties by a management association.

\section{Notes}

242017 OECD Comm (Draft), Art. 29, paras 101-112.

25 DANON, SALOME, MLI, s. 3.7.1.

262015 OECD, Final Report on Treaty Abuse, para. 26 (Commentary in para. 7); 2017 OECDComm (Draft), Art. 29, para. 175.

27 Arguably, the objective test of the anti-conduit rule contained in Art. 3(1)(n) of the 2001 US-UK tax treaty will also not be satisfied to this fact pattern. Hence, treaty benefits should be extended.

28 The HMRC seems to adopt a similar position in treaty shopping cases. See Examples 7 and 8 discussed in HMRC, Double taxation claims and applications - Beneficial ownership, INTM 332080

292015 OECD, Final Report on Treaty Abuse, para. 26 (Commentary in para. 3); 2017 OECD Comm (Draft), Art. 29, para. 171.

302014 OECD Comm. Art. 10, para. 12.2.

312015 OECD, Final Report on Treaty Abuse, para. 26 (Commentary in para. 14, Example I); 2017 OECD Comm (Draft), Art. 29, para. 182, Example I. 
13. It is less clear whether intermediaries (companies or other similar taxpayers), that receive passive income on their own behalf and forward all or a certain percentage of that income to others (through dividends or deductible expenses), qualify as 'beneficial owners' ${ }^{32}$ ? Although discussing the concept of 'beneficial owner' is beyond the scope of this contribution, the author states that international consensus does not seem to exist on this issue ${ }^{33}$ as some jurisdictions adopt a formal/legal approach (such as $\mathrm{Canada}^{34}$ ) whereas others adopt a more economic substance oriented approach (such as Switzerland ${ }^{35}$ ) to interpret this clause. In the author's opinion, the concept of 'beneficial ownership' should receive a narrow formal/legal meaning. ${ }^{36}$ The narrow meaning would exclude agents and nominees (as the income is not paid to them) ${ }^{37}$ but not companies that receive income on their own behalf and are taxable on the income (this does not mean that the clause should not be read as a subject to tax clause $^{38}$ ). In fact, several fact patterns that have been litigated before Courts in light of the 'beneficial ownership' clause are now discussed in the commentary to the PPT. For instance, refer to the discussion in the previous contribution with respect to Example $\mathrm{A}^{39}$ and Example $\mathrm{B}^{40}$ to the PPT as well as Example $\mathrm{C}^{41}$ and Example $\mathrm{E}^{42}$ to the commentary on anticonduits (see sections 4.2.1 and 4.3.2.6 of the previous contribution). This development clearly indicates that treaty abuse issues with respect to intermediary companies (or arrangements with intermediary companies) should be analysed under the PPT (or the guiding principle) as opposed to the beneficial ownership clause ${ }^{43}$ Thus, the role of the beneficial ownership clause in countering treaty abuse will diminish going forward.

\subsubsection{PPT and Other SAARs}

\subsubsection{Provision Countering Abusive Dividend Transfers}

14. Refer to the facts in example $\mathrm{E}^{44}$ to the PPT. Moving away from those facts slightly; assume that RCO purchases the shares of the distributing company from another shareholder $(\mathrm{Mr} \mathrm{X})$ with the sole intention to benefit from the reduced rate of $5 \%$ provided under Article 10(2)(a). After receiving the dividends, RCO immediately sells the shares back to $\mathrm{Mr}$ X. The commentary on Article 10 of the OECD Model provides that 'the reduction envisaged in subparagraph a) of paragraph 2 should not be granted in cases of abuse of this provision, for example, where a company with a bolding of less than 25 per cent has, shortly before the dividends become payable, increased its holding primarily for the purpose of securing the benefits. ${ }^{45}$ The PPT could apply to the case and RCO could be denied treaty benefits. ${ }^{46}$

\section{Notes}

32 The commentary provides that 'a conduit company cannot normally be regarded as the beneficial owner if, though the formal owner, it has, as a practical matter, very narrow powers which render it, in relation to the income concerned, a mere fiduciary or administrator acting on account of the interested parties'. See 2014 OECD Comm. Art. 10, para. 12.3.

33 Danon \& Salome, MLI, s. 3.7.4; De Broe, Thesis, at 713.

34 Arnold, Beneficial Ownership, at 44-48.

35 Danon \& Salome, MLI, s. 3.7.4.2.

36 Ibid., s. 3.7.4.3

37 For a discussion on the concept of 'paid to' see Sanghavi, Thesis, Ch. 5, s. 2.2.2.

38 See Chand, Thesis, s. 21.4.

392015 OECD, Final Report on Treaty Abuse, para. 26 (Commentary in para. 14, Example A); 2017 OECD Comm (Draft), Art. 29, para. 182, Example A. Also see 1994 Royal Dutch Oil Company/Marketmaker judgment. For a detailed analysis of the judgment see De Broe, Thesis, at 694-697; Smit, Beneficial Ownership, at 61-75; Ringler, Beneficial Ownership, at 222-223.

402015 OECD, Final Report on Treaty Abuse, para. 26 (Commentary in para. 14, Example B); 2017 OECD Comm (Draft), Art. 29, para. 182 , Example B. Also see the 2006 Bank of Scotland judgment. For a detailed analysis of the judgment see: De Broe, Thesis, at 697-702; Chand, Thesis, s. 13.4.10; Gutmann, Beneficial Ownership, at 167-182; Ringler, Beneficial Ownership, at 233-235.

412015 OECD, Final Report on Treaty Abuse, para. 26 (Commentary in para. 19, Example C); 2017 OECD Comm (Draft), Art. 29, para. 187, Example C. The example seems to contain a mixture of facts discussed in the 1971 Aiken Industries case and the 1997 Northern Indiana Public Service case. See Aiken Industries, Inc vs Commissioner of Internal Revenue, 56 TC 925, August $5^{\text {th }} 1971$ and US Court of Appeals for Seventh Circuit: Northern Indiana Public Service Company v. Commissioner, 115 F3d 506 , June 6 ${ }^{\text {th }} 1997$.

422015 OECD, Final Report on Treaty Abuse, para. 26 (Commentary in para. 19, Example E); 2017 OECD Comm (Draft), Art. 29, para. 187, Example E; Also see the discussion on the US SDI Netherlands (1996) case in Brauner, Beneficial Ownership, at 149-154; Ringler, Beneficial Ownership, at 207-208. Also see the Velcro Canada Case (2012) in Arnold, Beneficial Ownership, at 44-48; Ringler, Beneficial Ownership, at 229-230.

43 See De Broe, Thesis, at 714 . The commentator had suggested that the issue of conduit companies should be addressed through the adoption of the LOB clause or a main purpose test as opposed to the beneficial owner clause.

442015 OECD, Final Report on Treaty Abuse, para. 26 (Commentary in para. 14, Example E); 2017 OECD Comm (Draft), Art. 29, para. 182, Example E.

452014 OECD Comm. Art. 10, para. 17

462011 UN Comm. Art. 1, paras 94-95. 
15. Now assume that the R-S tax treaty contains the clause proposed by Article $8(1)$ of the MLI. ${ }^{47}$ The clause introduces a holding period of 365 days. After purchasing the shares, RCO receives the dividends, holds onto the shares of the distributing entity for one year and then sells them back to $\mathrm{Mr}$ $\mathrm{X}$. State $\mathrm{S}$ will not be able to refuse access to the lower rate of $5 \%$ as RCO has complied with the holding period. Therefore, the treaty SAAR will not apply. The question is whether the PPT can apply to the same fact pattern? The term 'notwithstanding' would indicate that the PPT will also apply. However, as stated earlier, the interpretation doctrine of lex specialis derogat legi generali should continue to apply when such anti-abuse rules apply to similar fact patterns ${ }^{48}$ (the guiding principle should definitely not apply). Even if the subjective element of the PPT gets satisfied, the author's opinion is that the taxpayer may be able to establish that it has acted in accordance with the 'object and purpose of the relevant provisions' (objective element). Specifically, the taxpayer may argue that it acts in accordance with the relevant provisions dealing with countering abusive dividend transfers and thus the PPT should not apply. In other words, the abusive, artificial or tax avoidance element switches off as the taxpayer complies with the holding period.

\subsubsection{Provision Countering Avoidance of Capital Gains on Sale of Real Estate}

16. Consider the following example: A resident individual investor, $\mathrm{Mr} \mathrm{X}$, of State $\mathrm{R}$ owns shares in a State S company viz., B Corp that owns only moveable and immoveable property. The shares derive $49 \%$ of their value from moveable property and $51 \%$ from immoveable property. If $\mathrm{Mr} \mathrm{X}$ sells the shares of B Corp, then his gain will be taxed in State $S$ pursuant to Article 13(4) of the OECD Model which provides that, 'Gains derived by a resident of a Contracting State from the alienation of shares deriving more than 50 per cent of their value directly or indirectly from immovable property situated in the other Contracting State may be taxed in that other State. ${ }^{49}$ In order to avoid State S taxes, Mr X injects cash into B Corp (through an increase of share capital). The addition of liquid assets increases the value of the moveable property to $51 \%$ and reduces the value of immoveable property to $49 \%$. Mr X sells the shares soon after injecting the cash. In this situation the PPT would surely apply, as the sole purpose for $\mathrm{Mr} \mathrm{X}$ to inject cash, immediately before the sale, is to circumvent taxes in State S. ${ }^{50}$

17. Now assume that the R-S tax treaty has adopted the clause proposed by Article 9(1) of the MLI. ${ }^{51}$ The clause introduces a time period of 365 days. After injecting the cash, $\mathrm{Mr} \mathrm{X}$ holds onto the shares of $\mathrm{B}$ Corp for one year. Thereafter, he makes the sale. The value of immoveable property remains the same throughout that one year. State $\mathrm{S}$ will not be in a position to tax the gain as less than $50 \%$ of the sale value is attributable to the immoveable property. Therefore, the treaty SAAR will not apply. The question is whether the PPT can apply to the same fact pattern? The term 'notwithstanding' would indicate that the PPT will also apply. However, as stated earlier, the interpretation doctrine of lex specialis derogat legi generali should continue to apply when such anti-abuse rules apply to similar fact patterns ${ }^{52}$ (the guiding principle should definitely not apply). Even if the subjective element of the PPT gets satisfied, the author's opinion is that the taxpayer may be able to establish that it has acted in accordance with the 'object and purpose of the relevant provisions' (objective element). Specifically, the taxpayer may argue that it acts in accordance with the relevant provisions dealing with countering avoidance of capital gains on the sale of shares of real estate companies and thus the PPT should not apply. In other words, the abusive, artificial or tax avoidance element switches off as the taxpayer complies with the time period.

\section{Notes}

472016 OECD, Multilateral Convention, Art. 8(1). It should be noted that this clause is an optional clause that States may wish to apply to their Covered Tax Agreements. See 2016 OECD, Explanatory Statement to the Multilateral Convention, para. 125. Only a few countries have opted for this clause with respect to their covered tax agreements. For instance, see the positions adopted by Argentina, Australia, Belgium, China, India and Russia.

48 Danon \& Salome, MLI, s. 3.7.3

492014 OECD Model, Art. 13(4).

502011 UN Comm. Art. 1, paras 97-99.

512016 OECD, Multilateral Convention, Art. 9(1). It should be noted that this clause is an optional clause that States may wish to apply to their Covered Tax Agreements. See 2016 OECD, Explanatory Statement to the Multilateral Convention, para. 136. A few countries have opted for this clause with respect to their covered tax agreements. For instance, see the positions adopted by Argentina, Australia, Belgium and China.

52 Danon \& Salome, MLI, s. 3.7.3. 


\subsubsection{Anti-Abuse Rule for Third State Permanent Establishments}

18. Consider the following example: A resident of State R that carries out an operating business, RCO, derives interest income from SCO in State S. The interest income is attributable to RCOs PE in State $\mathrm{T} .{ }^{53}$ The corporate tax rate in State $\mathrm{R}$ and State $\mathrm{T}$ are $25 \%$ and $9 \%$, respectively. The domestic withholding tax rate in State S on interest income is $30 \%$. The $\mathrm{R}-\mathrm{S}$ treaty provision dealing with interest provides for nil taxes at source whereas the $\mathrm{R}-\mathrm{T}$ tax treaty contains a clause equivalent to Article 23A(1) of the OECD Model that deals with the exemption method. In this situation, State $\mathrm{S}$ will not be able to tax the interest, State $\mathrm{T}$ will tax the interest at $9 \%$ and State $\mathrm{R}$ will exempt the income from taxation. ${ }^{54}$ Now assume that the R-S tax treaty has adopted the clause proposed by Article 10 of the MLI. ${ }^{55}$ In this situation, RCO may not be extended treaty benefits pursuant to Article 10(1) as the tax imposed in State $\mathrm{T}$ is less than $60 \%$ of the tax imposed in State $\mathrm{R}$ on that interest income. ${ }^{56}$ Also, RCO may not satisfy the active conduct test contained in Article 10(2) as its $\mathrm{PE}$ is in the business of making and managing investments. ${ }^{57}$ In these circumstances, the PE antiabuse rule will take precedence to deny treaty access and the PPT (or guiding principle) will not apply.

19. All facts remaining the same, assume that the corporate tax rate in State $\mathrm{R}$ is $12.5 \%$. In this situation, treaty benefits will have to be extended to RCO as the tax imposed in State $\mathrm{T}$ is more than $60 \%$ of the tax imposed in State $\mathrm{R}$ on that interest income. Can State $\mathrm{S}$ deny treaty benefits to RCO by applying the PPT? In the author's opinion, the PPT should not apply to a fact pattern that falls under the scope of the anti-abuse clause and in such situations the interpretation doctrine of lex specialis derogat legi generali should continue to apply ${ }^{58}$ (the guiding principle should definitely not apply). Even if applied the author is of the opinion that the subjective element of the test should not be satisfied given the fact that RCO and its branch are carrying out genuine business activities (see section 3.4 of the previous contribution).

\section{Domestic anti-AVOIDANCE RULES}

\section{I Types of Domestic Anti-Avoidance Rules}

20. A distinction should be made between domestic anti-avoidance rules that counteract treaty abuse ${ }^{59}$ (i.e. deny treaty benefits when the taxpayer engages in treaty or rule shopping or any scheme that is employed to obtain treaty benefits inappropriately) and domestic anti-avoidance rules that counteract abuse of domestic law $^{60}$ (such as rules that deny deductions to resident taxpayers, impute income in the hands of resident taxpayers or deem a resident taxpayer to alienate its assets prior to its migration). The section focuses on the former type of anti-avoidance rules.

\subsection{Interaction of Domestic Anti-Avoidance Rules with Tax Treaties}

21. Treaty or rule shopping (or other forms of treaty abuse) can be counteracted at the domestic law level by judicial anti-abuse rules (such as substance over form or economic substance, ${ }^{61}$ step transactions ${ }^{62}$ or business purpose tests ${ }^{63}$ or other doctrines ${ }^{64}$ ), domestic statutory GAARs ${ }^{65}$ or domestic SAARs (source

\section{Notes}

53 We assume that RCOs branch (PE) carries out financing activities such as loan creation or loan management activities for the entire multinational group and bears the associated financing related risks.

542017 OECD Comm (Draft), Art. 29, para. 163.

552016 OECD, Multilateral Convention, Art. 10; It should be noted that this clause is an optional clause that States may wish to apply to their Covered Tax Agreements. See 2016 OECD, Explanatory Statement to the Multilateral Convention, para. 145. Only a few countries have opted for this clause with respect to their covered tax agreements. For instance, see the positions adopted by Argentina, Austria and Netherlands.

562017 OECD Comm (Draft), Art. 29, paras 165-166.

572017 OECD Comm (Draft), Art. 29, para. 167

58 Danon \& Salome, MLI, s. 3.7.1.

59 The object of abuse in these situations is the provisions of the tax treaty. See De Broe, Luts, BEPS, at 125.

60 The object of abuse in these situations are the provisions of the domestic law. The treaty is used subsequently to neutralize the application of the domestic anti-avoidance rule. See De Broe, Luts, BEPS, at 125.

61 See CHAND, Thesis, s. 3.2.2.

62 Ibid., s. 3.2.3.

63 Ibid., s. 3.2.4.

64 Ibid., s. 3.2.5 and 3.2.6.

65 Ibid., s. 3.3 . 
State measures such as anti-treaty shopping rules/antirule shopping rules $\left.{ }^{66}\right)$. The question arises as to how do these rules interact with tax treaties? Although discussing the interaction between domestic antiavoidance rules and tax treaties is beyond the scope of this contribution, the OECD's view on the interaction of domestic SAARs with tax treaties seems to be different when compared to its own view on the interaction of domestic statutory GAARs/judicial doctrines with tax treaties. With respect to the former, the commentary does acknowledge that conflicts could arise. ${ }^{67}$ This is illustrated through an example that deals with transfer of residence. ${ }^{68}$ Nevertheless, the commentary does indicate that the guiding principle/PPT could be applied to deny the treaty benefit. With respect to the latter, the commentary states that in a vast majority of situations conflicts will not arise. Specifically, in the context of domestic statutory GAARs, the commentary states that conflicts will not arise where the 'main aspects of these domestic general antiabuse rules are in conformity with' the PPT or the guiding principle (in case the treaty does not incorporate the PPT). ${ }^{69}$ Likewise, with respect to the interaction of judicial doctrines with tax treaties, the commentary states that having regard to the guiding principle (or the PPT), 'there will be no conflict between tax conventions and judicial antiabuse doctrines or general domestic anti-abuse rules. ${ }^{70}$ The author states that domestic law and treaty law are two different legal spheres. The commentary on Article 1 seems to mix these spheres by referring to the PPT and guiding principle during its discussion on the interaction of domestic anti-avoidance rules with tax treaties. Such references to treaty anti-abuse rules create confusion.

22. In the author's opinion, the application of judicial anti-abuse rules, domestic statutory GAARs or domestic SAARs can have several 'effects' in treaty or rule shopping situations (or other forms of treaty abuse). Whether or not such 'effects' of applying domestic anti-abuse rules conflict with a tax treaty depends on the wording and purpose of the relevant treaty provision. If the domestic anti-avoidance 'effect' does not square with the terms of the tax treaty then the latter will prevail pursuant to Article 26 of the VCLT that contains the "pacta sunt servanda' principle. In fact, in the opinion of the author, when a domestic anti-avoidance rule is applied from the source State's perspective and its 'effects' lead to the conclusion that (1) the taxpayer is redetermined ${ }^{71}$ (2) the income is re-characterized ${ }^{72}$ or (3) a treaty benefit is denied, ${ }^{73}$ in many situations, conflicts can arise between domestic anti-avoidance rules and tax treaties that are based on the OECD Model. Also, if such rules are applied or introduced after the conclusion of the tax treaty - a treaty override occurs.

23. This being said, the author states that if a tax treaty has a safeguard clause, which authorizes a State to apply domestic anti-avoidance rules, then it cannot be argued that a conflict arises. ${ }^{74}$ In this regard, particular attention should be given to issues surrounding the scope of the safeguard clause and its interpretation (static or ambulatory approach). ${ }^{75}$ Moreover, domestic anti-avoidance rules can be used to interpret undefined treaty terms. This is because Article 3(2) of the OECD Model makes a reference to the domestic law of the State applying the treaty. As domestic anti-avoidance rules form part of the domestic tax law of the State applying the treaty such rules can be called into play to give a meaning to an undefined treaty term. Consequently, if a domestic judicial doctrine, statutory GAAR or even a SAAR is applied to give a meaning to an undefined treaty term then that meaning will take precedence. ${ }^{76}$ This position is of course subject to the limitation that the 'context' (internal and external) of

\section{Notes}

66 Ibid., s. 3.4.2.1.

672017 OECD Comm (Draft), Art. 1, para. 70.

682017 OECD Comm (Draft), Art. 1, para. 74.

692003 OECD Comm. Art. 1, paras 22-22.1; 2015 OECD, Final Report on Treaty Abuse, para. 59 (Commentary in paras 26.3-26.4); 2017 OECD Comm (Draft), Art. 1, paras $76-77$

702003 OECD Comm. Art. 1, paras 22-22.1; 2015 OECD, Final Report on Treaty Abuse, para. 59 (Commentary in paras 26.5-26.7); 2017 OECD Comm (Draft), Art. 1, paras $78-80$

See Chand, Thesis, Ch. 13.

Ibid., Ch. 14

Ibid., Ch. 15 .

2017 OECD Comm (Draft), Art. 1, para. 72 and para. 77

Ibid., Ch. 10

762017 OECD Comm (Draft), Art. 1, para. 73 and para. 77 
the tax treaty and/or the interpretation principles of the VCLT may not require a reference to a domestic law provision. $^{77}$

24. There is no doubt that several issues arise from the application of domestic anti-abuse rules to cross border situations that are governed by tax treaties. Therefore, domestic anti-abuse rules should not be used to counter treaty abuse. Specifically, they should not be used because such rules express unilateral application of the domestic law. Such unilateral application could reallocate taxing rights and lead to double taxation (juridical or economic). Consequently, the application of tax treaties becomes less certain and more controversial when domestic anti-abuse rules are applied. Accordingly, it is recommended that only treaty anti-abuse rules be used to counter treaty abuse. In other words, treaty abuse (treaty shopping, rule shopping or other similar schemes) should be counteracted only by treaty measures such as the PPT, LOB clause or other targeted SAARs. This is because such rules, when incorporated in tax treaties, express the common intentions of the treaty partners. With respect to the implementation of the minimum standard, the OECD had suggested States to apply the detailed LOB clause coupled with either a treaty antiabuse rule or domestic anti-abuse measures to counteract conduit financing. In light of the foregoing discussion, in the author's opinion, States should not use domestic anti-abuse rules to counter treaty abuse when they opt for the detailed LOB clause.

\section{Key conclusions}

25. The PPT (if incorporated in a tax treaty) will prevail over the inherent anti-abuse rule. Further, as a result of the compatibility clause, the PPT will replace existing treaty GAARs that have a broad/ restricted scope. Moreover, as demonstrated, it is submitted that the PPT (and the guiding principle) should not apply to fact patterns that are covered by other treaty SAARs. Also, going forward, issues with respect to intermediary companies (as well as arrangements with such companies) should be analysed under the PPT (or guiding principle - till the extent relevant) as opposed to the beneficial ownership clause. On the other hand, domestic anti-abuse rules should not be used to counter treaty abuse as they could conflict with treaty provisions. Moreover, such rules could reallocate taxing rights and lead to double taxation (juridical or economic). Consequently, the application of tax treaties becomes less certain and more controversial. Therefore, it is recommended that only treaty anti-abuse rules be used to counter treaty abuse. Of course, whether or not the treaty anti-abuse rule is applicable will depend on the precise facts and circumstances of each situation.

\section{Additional Bibliography}

Kindly refer to the previous contribution for a detailed bibliography. In this section, the author only mentions that additional documents that were used to prepare this contribution.

Frank Engelen, On Values and Norms: The Principle of Good Faith in the Law of Treaties and the Law of Tax Treaties in Particular (Alphen aan den Rijn 2006) (quoted Engelen, Good Faith).

Dhruv Sanghavi, Resolving Structural Issues in Income Tax Treaties, (Forthcoming) (quoted Sanghavi, Thesis).

David Ward, Access to Tax Treaty Benefits, Research Report Prepared for the Advisory Panel on Canada's System of International Taxation 1-48 (2008), (quoted Ward, Abuse).

United Nations Statute of the International Court of Justice (quoted UN Statute of the ICJ).

Indian Supreme Court: Vodafone International Holdings B.V. vs Union of India, Civil Appeal No.733 of 2012, 20 Jan. 2012.

District Court of Tel Aviv-Yafo: Yanko-Weiss Holdings Ltd v. Holon Assessing Office, 10 ITLR 524, 524-550 (30 Dec. 2007). 